\title{
Detoxification of Gramine by the Cereal Aphid Sitobion avenae
}

\author{
Qing-Nian Cai • Ying Han • Ya-Zhong Cao • Yuan Hu• \\ Xin Zhao • Jian-Long Bi
}

Received: 26 October 2008 /Revised: 13 January 2009/Accepted: 21 January 2009 /Published online: 18 February 2009

(C) The Author(s) 2009. This article is published with open access at Springerlink.com

\begin{abstract}
Secondary metabolites play an important role in host plant resistance to insects, and insects, in turn, may develop mechanisms to counter plant resistance mechanisms. In this study, we investigated the toxicity of gramine to the cereal aphid Sitobion avenae and some enzymatic responses of $S$. avenae to this alkaloid. When $S$. avenae fed on an artificial diet containing gramine, mortality occurred in a dose-dependent manner. The $\mathrm{LC}_{50}$ of gramine was determined to be $1.248 \mathrm{mM}$. In response to gramine, $S$. avenae developed increased activities of carboxylesterase and glutathione $S$-transferase, two important detoxification enzymes. The activities of both enzymes were positively correlated with the concentration of dietary gramine. In addition, the activities of peroxidase and polypheolic oxidase, two important oxidoreductase enzymes in S. avenae, increased in response to gramine; however, catalase activity decreased when insects were exposed to higher levels of dietary gramine. The potential role of gramine in host plant resistance and $S$. avenae counter-resistance is discussed.
\end{abstract}

Keywords Gramine - Sitobion avenae - Carboxylesterase . Glutathione $S$-transferase · Peroxidase · Polyphenol oxidase · Catalase

Q.-N. Cai · Y. Han · Y. Hu • X. Zhao

College of Agronomy and Biotechnology,

China Agricultural University,

Beijing 100094, People's Republic of China

Y.-Z. Cao

Institute of Plant Protection,

Chinese Academy of Agricultural Science,

Beijing 100094, People's Republic of China

J.-L. Bi $(\bowtie)$

University of California Cooperative Extension,

Salinas, CA 93901, USA

e-mail: jbi@ucdavis.edu

\section{Introduction}

Host plant resistance against insects is recognized as an important component of integrated insect pest management (Gao 1994; Schotzko and Bosque-pérez 2000; Li et al. 2001). Plant resistance is attributed largely to secondary metabolites such as phenolics, nonprotein amino acids, and alkaloids, which are documented to be deleterious to insect herbivores (Manuwoto and Scriber 1985; Ciepiela and Sempruch 1999; Wang et al. 2006).

Many alkaloids are strong deterrents to aphids and other herbivores and have been used as botanical insecticides and/or antixenotic chemicals (Luo et al. 1997; Jiang et al. 1999). Gramine, a simple indole alkaloid found in barley and other crop plants, occurs widely in plants of Gramineae and has a wide range of biological activities against insects, mammals, and bacteria (Corcuera 1984, 1993; Züñiga and Corcuera 1986; Leszczynski et al. 1989).

In the plant-insect ecosystem, insect detoxification enzymes (i.e., esterase and glutathione $S$-transferase) and oxidoreductases (i.e., polyphenol oxidase, peroxidase, and catalase) are important antiresistant agents against the secondary metabolites found in their host plants. Their role in overcoming plant resistance has been studied extensively in a number of insect species (Gao et al. 1997; Figueroa et al. 1999; Luo and Zhang 2003). However, little is known about the changes of detoxification enzymes and oxidoreductases in aphids in response to gramine.

The present study was conducted to elucidate some of the biochemical mechanism(s) of gramine in host plant resistance and to determine how the English grain aphid, Sitobion avenae (F.), counters this resistance. The specific objectives were (1) to assess the direct toxicity of gramine to $S$. avenae and (2) to determine activities of detoxification enzymes and oxidoreductases in $S$. avenae in response to gramine in its diet. 


\section{Methods and Materials}

Insects Sitobion avenae nymphs and adults were collected from field-grown wheat and maintained on the aphid-susceptible cultivar "Beijing 411," under field conditions. Insects over two generations were used for experiments.

Diet Preparation and Gramine Toxicity To determine gramine toxicity to $S$. avenae, technical-grade gramine was incorporated into an artificial diet containing the following ingredients: $300 \mathrm{mg}$ agrinine, $50 \mathrm{mg}$ cysteine, $200 \mathrm{mg}$ histidine, $200 \mathrm{mg}$ lysine, $100 \mathrm{mg}$ methionine, $100 \mathrm{mg}$ phenylalanine, $100 \mathrm{mg}$ serine, $100 \mathrm{mg}$ tryptophan, $20 \mathrm{mg}$ tyrosine, $10 \mathrm{mg}$ ascorbic acid, $0.1 \mathrm{mg}$ biotin, $50 \mathrm{mg}$ choline chloride, $1.0 \mathrm{mg}$ folic acid, $10 \mathrm{mg} p$-aminobenzoic acid, $10 \mathrm{mg}$ nicotinic acid, $2.5 \mathrm{mg}$ pyridoxine $\mathrm{HCl}, 2.5 \mathrm{mg}$ thianine $\mathrm{HCl}, 500 \mathrm{mg} \mathrm{K}_{3} \mathrm{PO}_{4}, 200 \mathrm{mg} \mathrm{MgCl} 2 \cdot 6 \mathrm{H}_{2} \mathrm{O}, 100 \mathrm{ml}$ distilled water, and $25 \mathrm{~g}$ sucrose. The $\mathrm{pH}$ was adjusted to 6.0 with $\mathrm{K}_{3} \mathrm{PO}_{4}$ (Auclair 1965; Kieckhefer and Derr 1967; Chen et al. 2000). Gramine (Kingsley and Keith) was dissolved into the liquid artificial diet to get a range of concentrations $(4.0,2.0,1.0,0.5,0.25,0.125$, and $0.0 \mathrm{mM})$ for $\mathrm{LC}_{50}$ determination.

To assess effect of gramine on S. avenae detoxification enzymes and oxidoreductases and to ensure sufficient live aphids for biochemical analyses, technical grade gramine was dissolved in the artificial diet to compose four different concentrations $(0.025,0.05,0.1$, and $0.2 \mathrm{mM})$ below the $\mathrm{LC}_{50}$. A diet containing no gramine was used as the control.

The second-third instar nymphs of $S$. avenae were fed on the liquid diet held between two layers of Parafilm $\mathrm{M}^{\circledR}$ (Auclair 1965). Two layers of stretched Parafilm were placed in a transparent cylindrical Plexiglas tube (height $60 \mathrm{~mm}$ and diameter $22 \mathrm{~mm}$ ) and covered on top with gauze to allow air and humidity exchange. After $72 \mathrm{~h}$ of feeding, mortality was determined, and the survivors were collected for analyses of the detoxification enzymes and oxidoreductases.

Detoxification Enzyme Assays Carboxylesterase (CarE) activity was measured according to the method of $\mathrm{Ni}$ and Quisenberry (2003), with modification. Sitobion avenae $(50 \mathrm{mg}$ ) were homogenized in $0.02 \mathrm{M}$ potassium phosphate buffer $(2 \mathrm{ml} ; \mathrm{pH} 7.0)$ at $0^{\circ} \mathrm{C}$. The homogenate was centrifuged $\left(5,000 \times \mathrm{g}\right.$ at $4^{\circ} \mathrm{C}$ for $\left.15 \mathrm{~min}\right)$. An aliquot $(0.1 \mathrm{ml})$ of the resulting supernatant was mixed with $0.9 \mathrm{ml}$ of the solution containing a-NA and Fast blue RR salt (10 mg a-NA and $20 \mathrm{mg}$ Fast blue RR salt dissolved in $2 \mathrm{ml}$ acetone, and diluted to $25 \mathrm{ml}$ by adding the above phosphate buffer). The reaction progress was monitored spectrophotometrically at $405 \mathrm{~nm}$.
Glutathione $S$-transferase (GST) was measured according to $\mathrm{Ni}$ and Quisenberry (2003). Frozen $S$. avenae $(50 \mathrm{mg}$ ) were homogenized in $0.1 \mathrm{M}$ Tris- $\mathrm{HCl}$ buffer $(2 \mathrm{ml}$; $\mathrm{pH} 8.0)$ at $0^{\circ} \mathrm{C}$. The homogenate was centrifuged $\left(10,000 \times g\right.$ at $4^{\circ} \mathrm{C}$ for $15 \mathrm{~min})$. The assay mixture contained the resulting supernatant $(0.1 \mathrm{ml})$, the above described Tris- $\mathrm{HCl}$ buffer $(1.4 \mathrm{ml})$, and reduced glutathione $(40 \mathrm{mM} ; 50 \mu \mathrm{l})$. After a preincubation $\left(5 \mathrm{~min}\right.$ at $\left.25^{\circ} \mathrm{C}\right), \mathrm{CDNB}(30 \mathrm{mM} ; 60 \mu \mathrm{l})$ was added. Change in absorbance was monitored at $340 \mathrm{~nm}$.

Oxidoreductase Assays Aphids (50 mg) from each sample were ground in liquid nitrogen and then homogenized in $1 \mathrm{M}$ ice-cold potassium phosphate buffer $(1 \mathrm{ml})$ containing $1 \%$ polyvinylpyrrolidone and $1 \%$ Triton $\mathrm{X}-100$ at $\mathrm{pH} 7.0$. The homogenate was centrifuged $\left(10,000 \times g\right.$ at $4^{\circ} \mathrm{C}$ for $15 \mathrm{~min}$ ), and the supernatant was used for analyses of the following three oxidoreductases.

Peroxidase (POD) activity was measured using the method of Hildebrand et al. (1986) and Hori et al. (1997). Enzyme extract $(20 \mu \mathrm{l})$ was mixed with the substrate containing hydrogen peroxide $(30 \% ; 10 \mu \mathrm{l})$, guaiacol $(18 \mathrm{mM} ; 300 \mu \mathrm{l})$, and hydroxyethylpiperazine ethanesulfonic acid (HEPES) buffer in deionized water $(200 \mathrm{mM}$; $\mathrm{pH} 7.0 ; 100 \mu \mathrm{l})$. POD activity was estimated from the increase in $A_{470}$. The measurement was repeated three times.

Polyphenol oxidase (PPO) activity was determined following the method of Hori et al. (1997). Enzyme extract $(20 \mu \mathrm{l})$ was mixed with a solution containing $1.6 \%$ catechol in HEPES buffer $(500 \mu \mathrm{l}), 200 \mathrm{mM}$ HEPES $(\mathrm{pH} 6.0$; $100 \mu \mathrm{l})$, and deionized water $(380 \mu \mathrm{l})$. PPO activity was estimated from the increase in $A_{470}$. The analysis was repeated three times.

Catalase (CAT) activity was determined as described by Hildebrand et al. (1986) with minor modification. Enzyme extract $(20 \mu \mathrm{l})$ was mixed with a solution containing hydrogen peroxide $(75 \mathrm{mM} ; 100 \mu \mathrm{l})$, HEPES $(200 \mathrm{mM}$; pH $8.0 ; 100 \mu \mathrm{l})$, and deionized water $(780 \mu \mathrm{l})$. CAT activity was estimated from the increase in $A_{240}$. The analysis was repeated three times.

Total protein content was determined by the Bradford method (Bradford 1976). Absorbance of the reaction mixture was read at $595 \mathrm{~nm}$ with a spectrophotometer, and protein content was determined from a standard curve established using known quantities of bovine serum albumin (from Sigma Chemical) and the protein assay reagent.

Statistical Analysis Toxicity of gramine to $S$. avenae was subjected to probit analysis using the PriProbit Program V1.6.3 (Sakuma 1998). Analysis of variance was used to analyze the activity data from GST, CarE, POD, PPO, and CAT assays in $S$. avenae. Means were separated by the least significant difference test $(\alpha=0.05)$ (SPSS 11.0). 
Correlation between enzymatic activities and gramine concentrations was determined by correlation test $(\alpha=$ 0.05) (SPSS 11.0).

\section{Results}

Gramine Toxicity Gramine killed S. avenae when the insect was fed with the artificial diet containing higher concentrations of the alkaloid (Fig. 1). After $72 \mathrm{~h}$ of feeding, $S$. avenae mortality followed in a dosage-dependent manner. The $\mathrm{LC}_{50}$ was determined to be $1.248 \mathrm{mM}$ (range $0.947-$ $1.743 \mathrm{mM})$.

Effect of Gramine Enzyme Activity Total protein content of $S$. avenae varied after the aphids fed on the artificial diet containing gramine at various concentrations (Fig. 2). With the exception of aphids that fed on $0.025 \mathrm{mM}$ gramine, higher levels of total protein were found in all treatments compared to the control $(\mathrm{df}=4,10, F=275.34, P<0.001)$.

GST activity in $S$. avenae was influenced by artificial diets containing different amounts of gramine $(\mathrm{df}=4,10$, $F=58.66, P<0.001$ ) (Fig. 3 GST). GST activity was significantly greater in $S$. avenae that fed on the diet containing $0.05,0.1$, and $0.2 \mathrm{mM}$ of gramine than on the control diet. A positive correlation was observed between gramine concentration in diet and GST activity in $S$. avenae $(N=5 ; r=0.940 ; P=0.009)$.

CarE activity in $S$. avenae was also affected by the increased gramine in the diet $(\mathrm{df}=4,10, F=150.16, P<0.001)$ (Fig. 3 CarE). Gramine concentration was positively correlated with CarE activity in $S$. avenae $(N=5 ; r=0.889 ; P=0.022)$.

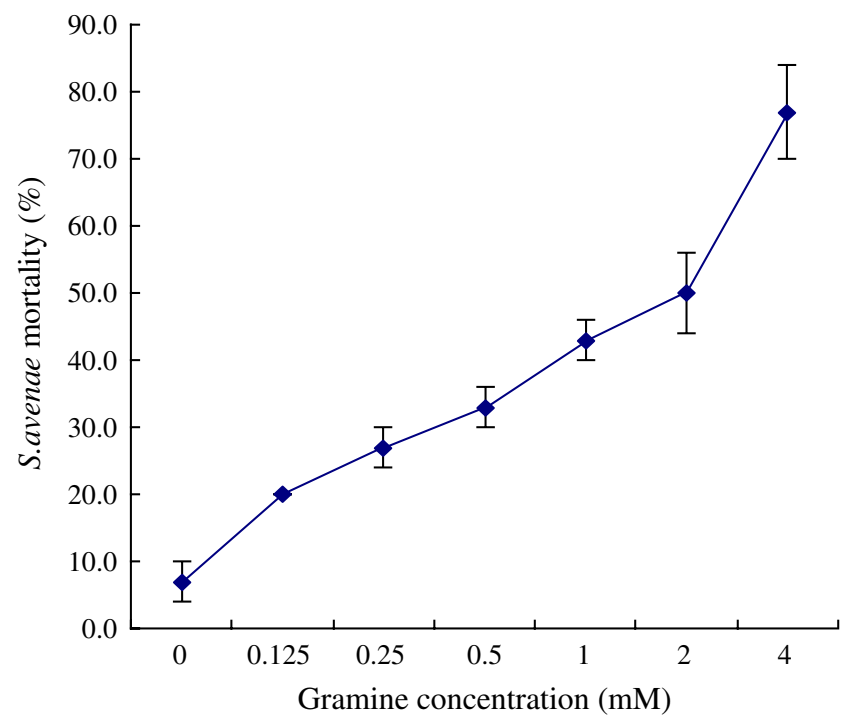

Fig. 1 Effect of gramine on the mortality of $S$. avenae at $72 \mathrm{~h}$ after treatment

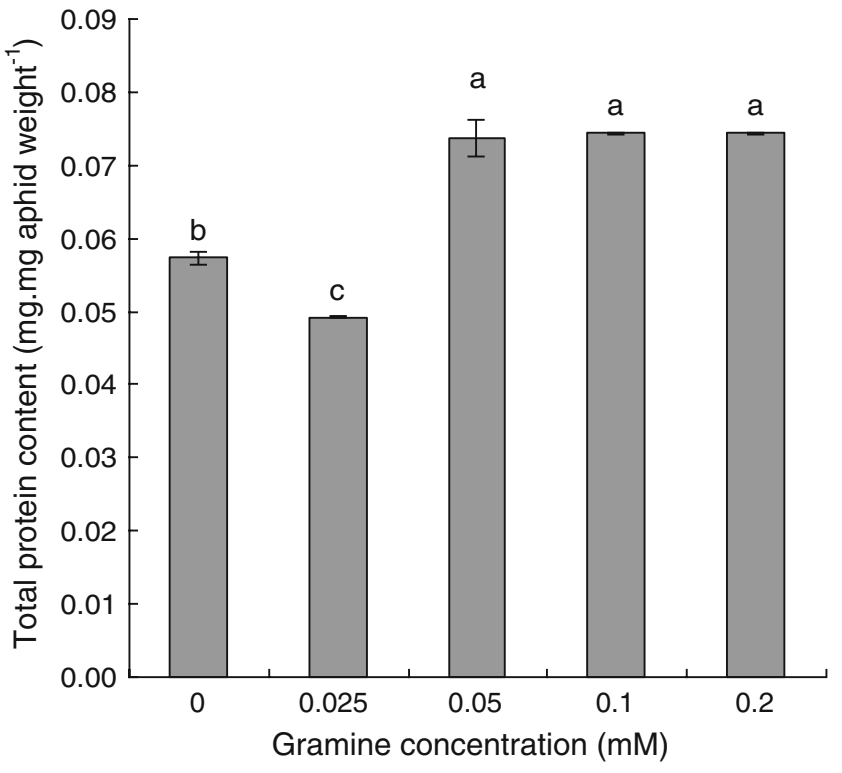

Fig. 2 Effect of different gramine concentrations on total protein content (mean $\pm \mathrm{SE}$ ) of $S$. avenae. Bars with different letters are significantly different $(P<0.05)$

POD and PPO activities were greater in S. avenae that fed on the artificial diet containing gramine than those on the control diet $\left(\mathrm{df}=4,10 ; F_{\mathrm{POD}}=113.20, F_{\mathrm{PPO}}=57.74, P<\right.$ 0.001) (Fig. 4 POD, PPO). Activities of both enzymes appeared to peak in $S$. avenae that fed on the diet containing $0.025 \mathrm{mM}$ gramine. Then, enzymatic activities gradually increased with increased gramine (between 0.05 and $0.2 \mathrm{mM}$ ). PPO activity was positively correlated with dietary gramine levels $(N=5 ; r=0.903 ; P=0.018)$. However, the correlation between POD activity and dietary gramine concentration was weak $(N=5 ; r=0.800 ; P=0.052)$.

With the exception of $0.025 \mathrm{mM}$ gramine treatment, CAT activity in $S$. avenae was suppressed by higher gramine concentration (between 0.05 and $0.2 \mathrm{mM})(\mathrm{df}=4$, $10 ; F=160.10 ; P<0.001$ ) (Fig. 4 CAT). The correlation between dietary gramine concentration and CAT activity was not significant $(N=5 ; r=-0.629 ; P=0.128)$.

\section{Discussion}

Many plant alkaloids are toxic to insects and are major resources of biological insecticides (Corcuera 1984; Jiang et al. 1999). Gramine has been considered as a deterrent and/or toxicant to many herbivorous insects such as Schizaphis graminum, Rhopalosiphum padi, S. avenae, and Locusta migratoria (Corcuera 1984; Zúñiga and Corcuera 1986; Leszczynski et al. 1989; Kanehisa et al. 1990; Rustamani et al. 1992; Moharramipour et al. 1997; Ishikawa and Kanke 2000; Wang et al. 2006). This study 

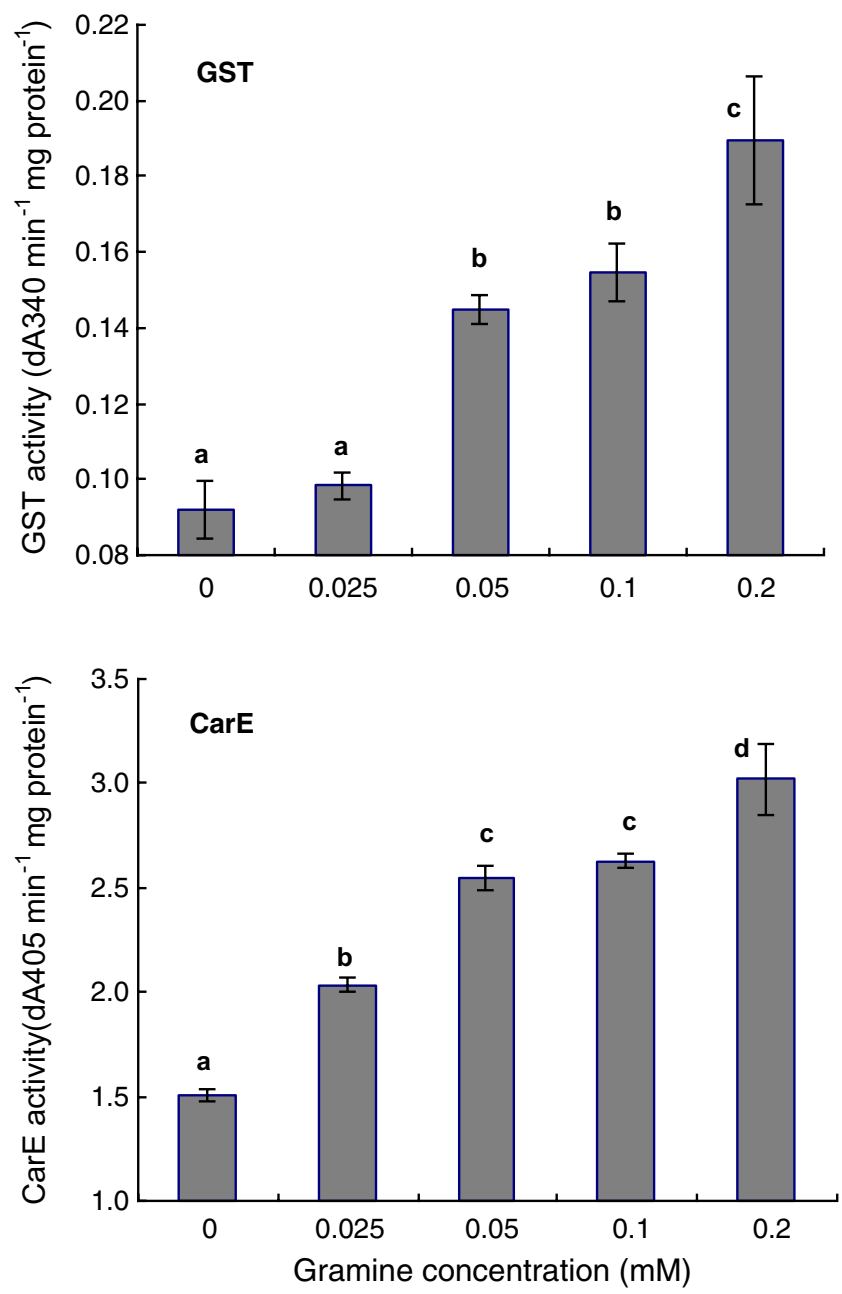

Fig. 3 Effect of gramine on activities (mean $\pm \mathrm{SE}$ ) of glutathione $S$ transferase (GST) and carboxylesterase (CarE) in $S$. avenae. Enzyme activities with different letters are significantly different $(P<0.05)$

showed that $S$. avenae mortality caused by exposure to dietary gramine was dosage-dependent with a defined $\mathrm{LC}_{50}$, providing further evidence that gramine is active in plant resistance against aphids.

Detoxification enzymes (i.e., CarE and GST) play an important role in insect counter-resistance to plant secondary metabolites. The activity of these insects is closely related to the level of secondary metablites in host plants. CarE activity varies significantly among the populations of Aphis gossypii collected from different cotton varieties (Gao 1992; Jiang and Guo 1996). A higher CarE activity was observed in $R$. padi from resistant wheat varieties compared to susceptible varieties (Chen et al. 1997; Cai et al. 2004). Previous studies showed that alkaloids have been used as insecticides to regulate esterase activity in Lipaphis erysimi (Katenbach) and Plutella xylostella (L.) (Luo et al. 1997). The indole alkaloid gramine used in this study increased

CarE activity in S. avenae, and the increase was positively correlated with dietary gramine concentrations, suggesting that CarE is involved with gramine detoxification.

GSTs (EC 2.5.1.18) constitute a group of enzymes that are involved in the detoxification of endogenous or
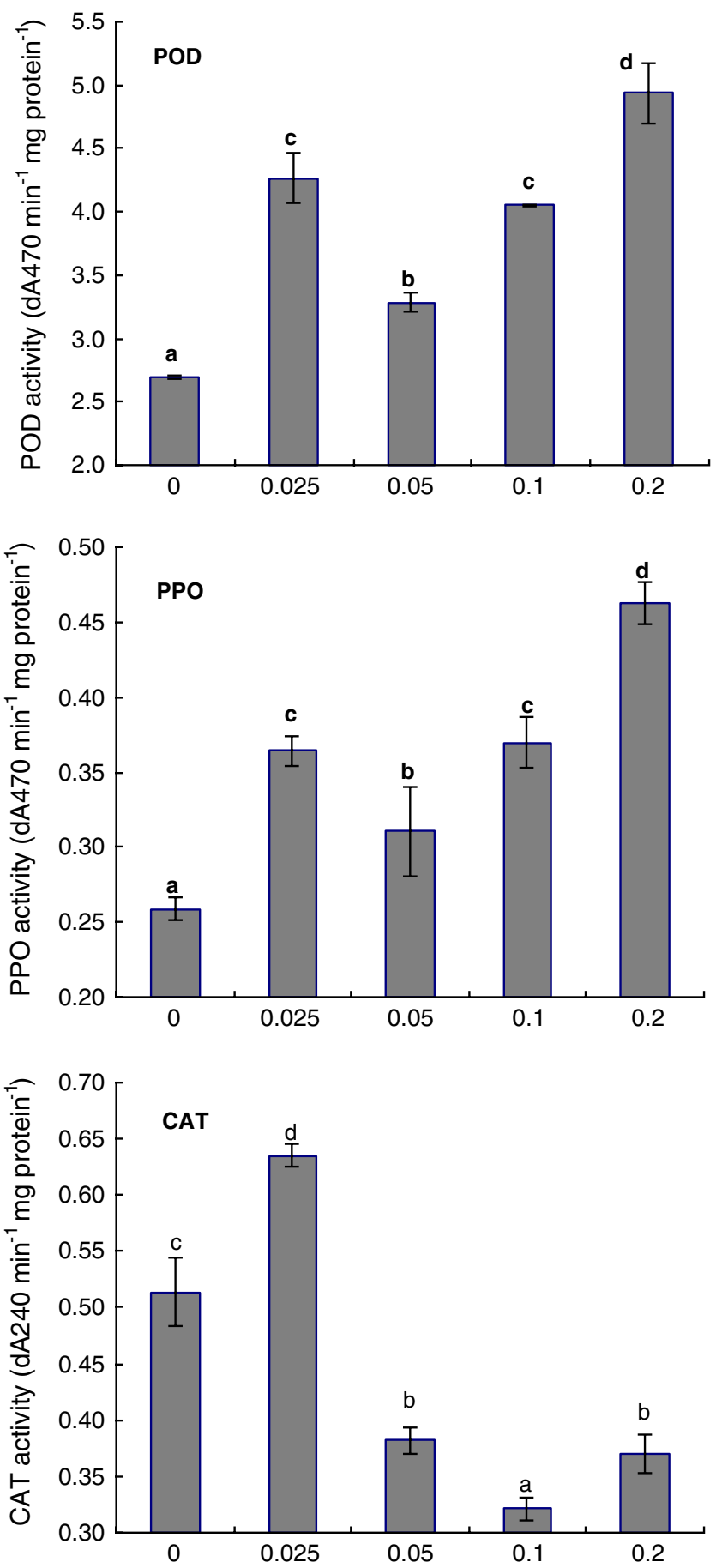

Fig. 4 Effect of gramine on activities (mean \pm SE) of peroxidase $(P O D)$, polyphenol oxidase $(P P O)$, and catalase $(C A T)$ in $S$. avenae. Enzyme activities with different letters are significantly different $(P<0.05)$ 
exogenous toxic compounds (Vos and van Bladeren 1990). Increased level of GSTs in insects has been associated with resistance to a variety of insecticides (Foumier et al. 1992). Leszczynski et al. (1993) reported that GST activity was higher in $S$. avenae that fed on resistant wheat cultivars with high concentrations of phenolic compounds than those that fed on the susceptible ones. In this study, increased GST activity in aphids was observed when they fed on diets containing higher gramine concentrations, and enzyme activity was positively correlated with gramine concentration (Fig. 3). These results indicate that GSTs play a positive role in aphid antiresistance against allelochemicals (e.g., phenolics and gramine) in cereals.

POD and PPO are oxidoreductases, and in phytophagous insects, they may be able to counter plant resistance by reducing plant phenolics and their derivatives (Urbanska and Leszczynski 1992; Leszczynski et al. 1993). Phenolic compounds are involved in the resistance of cereal against aphids (Leszczynski et al. 1985, 1996). When aphids fed on a diet containing different concentrations of gramine, significantly different activities of POD and PPO were detected among the concentrations, and the gramine concentrations were correlated strongly with PPO activity in aphids but weakly with POD activity (Fig. 4). These results suggest that both POD and PPO in aphids are involved in gramine metabolism.

CAT is the classical enzyme in aerobic organisms that catalyzes the decomposition of hydrogen peroxide. This enzyme occurs in the midgut of $S$. avenae (Felton and Duffey 1991; Urbańska 2007). Many plant phenolics enhance the enzymatic activity in S. avenae (Figueroa et al. 1999; LoayzaMuro et al. 2000; Lukasik 2007). Interestingly, the opposite was observed in the present study, as S. avenae CAT activity was strongly reduced by higher gramine concentrations. However, significant correlations were not found between the activity and gramine concentration. This suggests that $S$. avenae CAT may be dissimilarly modified by the different cereal allelochemicals, i.e., alkaloids vs. phenolics.

In summary, gramine is considered to be an important secondary metablite in host plant resistance. This study showed that dietary gramine was toxic to $S$. avenae. In response to gramine, $S$. avenae enhanced CarE and GST activities, as well as PPO and POD activities, thus possibly countering the resistance.

Acknowledgements This research was partly supported by the National Basic Research Program from Ministry of Science and Technology of the People's Republic of China ("973" Program, Grant No. 2006CB100206), Public Welfare Project from Ministry of Agriculture of People's Republic of China (Grant No. 200803002), National Support Program from Ministry of Science and Technology of People's Republic of China (Grant No. 2006BAD08A05) and the Initiation Research Program of China Agricultural University (Grant No. 2004050).
Open Access This article is distributed under the terms of the Creative Commons Attribution Noncommercial License which permits any noncommercial use, distribution, and reproduction in any medium, provided the original author(s) and source are credited.

\section{References}

AUCLAIR, J. I. 1965. Feeding and nutrition of the pea aphid, Acyrthosiphon pisum (Homoptere: Aphidae), on chemical defined diets of various $\mathrm{pH}$ and nutrient levels. Ann. Entomol. Soc. Am. 58:855-875.

BRADFORD, M. M. 1976. A rapid and sensitive method for the quantitation of microgram quantities of protein utilizing the principle of protein-dye binding. Anal. Biochem. 72:248-254.

CAI, Q. N., ZhANG, Q. W., and CheO, M. 2004. Contribution of indole alkaloids to Sitobion avenae (F.) resistance in wheat. J. Appl. Entomol. 128:517-521.

Chen, J., Song, D., Cai, C., Cheng, D., and Tian, Z. 1997. Biochemical studies on wheat resistance to the grain aphid, Rhopalosiphum padi (L.). Acta Entomol. Sinica 40:186-189(In Chinese with English abstract).

Chen, J., Ni, H., DinG, H., and SuN, J. 2000. Studies on a chemically defined diet of English grain aphid. Sci. Agric. Sinica 33:54-59 (In Chinese with English abstract).

Ciepiela, A. P., and Sempruch, C. 1999. Effect of L-3, 4dihydroxyphenylalanine, ornithine and $\gamma$-aminobutyric acid on winter wheat resistance to grain aphid. J. Appl. Entomol. 123:285-288.

CORCUERA, L. J. 1984. Effects of indole alkaloids from gramineae on aphids. Phytochemistry 23:539-541.

CorcuerA, L. J. 1993. Biochemical basis for the resistance of barley to aphids. Phytochemistry 33:741-747.

Felton, G. W., and Duffey, S. S. 1991. Protective action of midgut catalase in lepidopteran larvae against oxidative plant defenses. J. Chem. Ecol. 17:1715-1732.

Figueroa, C. C., Koenig, C., Araya, C., Santos, M. J., and NIEMEYER, H. M. 1999. Effect of DIMBOA, a hydroxamic acid from cereals, on peroxisomal and mitochondrial enzymes from aphids: evidence for the presence of peroxisomes in aphids. J. Chem. Ecol. 25:2465-2475.

Foumier, D., Bride, J. M., Poirie, M., Berge, J. B., and Plapp, F. W. Jr. 1992. Insect glutathione S-transferases: biochemical characteristics of the major forms from houseflies susceptible and resistant to insecticides. J. Biol. Chem. 267:1840-1845.

GAO, X. 1992. Effects of host plant on carboxylesterase activity in cotton aphid Aphis gossypii Glov. Acta Entomol. Sinica 35:267272(In Chinese with English abstract).

GAO, C. S. 1994. Influence of resistance of wheat varieties to the population growth of Macrosiphum avenae (F.). Entomol. Knowl. 31:201-205(In Chinese with English abstract).

Gao, X. W., Dong, X. L., Zheng, B. Z., and Chen, Q. 1997. Glutathione S-transferase (GSTs) of Helicoverpa armigera: Induction of insecticides and plant allelochemicals and metabolism of insecticides. Acta Entomol. Sinica 40:122-127(In Chinese with English abstract).

Hildebrand, D. F., Rodriguez, J. G., Brown, G. C., LuU, K. T., and VOLDEN, C. S. 1986. Peroxidative responses of leaves in two soybean genotypes injured by twospotted spider mites (Acari: Tetranychidae). J. Econ. Entomol. 79:1459-1465.

Hori, K., WADA, A., and SHIBUTA, T. 1997. Changes in phenoloxidase activities of the gals on leaves of Ulmus davidana formed by Tetraneura fusiformis (Homoptera: Eriosomatidae). Appl. Entomol. Zool. 32:365-371. 
ISHIKAWA, Y., and KANKE, T. 2000. Role of gramine in the feeding deterrence of barley against the migratory locust, Locusta migratoria (Orthoptera: Acrididae). Appl. Entomol. Zool. 35:251-256.

JiANG, Y., and GuO, Y. 1996. Study of carboxylesterase activity of cotton aphid fed on different cotton varieties. Acta Gossypii Sinica 8:215-218(In Chinese with English abstract).

JIANG, S., LIU, J., and LAN, Z. 1999. Insecticidal effects of three kinds of alkaloids on wheat aphids. J. Gansu Agri. Univ. 4:361-364(In Chinese with English abstract).

Kanehisa, K., TsumuKi, H., Kawada, K., R, and Ustamani, M. A. 1990. Relations of gramine contents and aphid populations on barley lines. Appl. Entomol. Zool. 25:251-259.

KIECKHEFER, R. W., and DERR, R. F. 1967. Rearing three species of cereal aphids on artificial diets. J. Econ. Entomol. 60:663-665.

LeszcZynski, B., UrbansKa, A., MatoK, H., and Dixon, A. F. G. 1993. Detoxifying enzymes of the grain aphid. Bull. OILB SROP $16: 165-172$.

Leszczynski, B., BAKowski, T., RozbickA, B., Matok, H., UrBANSKA, A., and DiXON, A. F. G. 1996. Interaction between cereal phenolics and grain aphid (Sitobion avenae Fabr.). Bull. OILB SROP 19:100-105.

LESZCZYNSKI, B., WARCHOL, J., and NIRAZ, S. 1985. The influence of phenolic compounds on the preference of winter wheat cultivars by cereal aphids. Insect Sci. Appl. 6:157-158.

LESZCZYNSKI, B., Wright, L. C., and BAKOWSKI, T. 1989. Effect of secondary plant substances on winter wheat resistance to grain aphid. Entomol. Exp. Appl. 52:135-139.

LI, S. J., LiU, A. Z., WU, Y. Q., LI, S. G., LU, X. H., and Yin, H. E. 2001. Population dynamics of wheat aphids and natural enemies in different wheat varieties. Entomol. Knowl. 38:355-358(In Chinese with English abstract).

Loayza-Muro, R., Figueroa, C. C., and Niemeyer, H. M. 2000. Effect of two wheat cultivars differing in hydroxamic acid concentration on detoxification metabolism in the aphid Sitobion avenae. J.Chem. Ecol. 26:2725-2736.

LUKASIK, I. 2007. Changes in activity of superoxide dismutase and catalase within cereal aphids in response to plant $o$-dihydroxyphenols. J. Appl. Entomol. 131:209-214.

LuO, W. C., and ZHANG, Q. 2003. Effects of Sophora alopecuroids alkaloids on metabolic esterases of the diamondback moth. Acta Entomol. Sinica 46:122-125(In Chinese with English abstract).
LuO, W., LI, Y., and MU, L. 1997. The toxicities of alkaloids from Sophora alopecuroids against turnip aphid and effect on several esterases. Acta Entomol. Sinica 40:385-365(In Chinese with English abstract).

MANUwoto, S., and ScriBer, M. 1985. Consumption and utilization of experimentally altered corn by Southern armyworm: iron, nitrogen, and cyclic hydroxamates. J. Chem. Ecol. 11:14691483.

Moharramipour, S., Tsumuki, H., Sato, K., Murata, S., and KANEHISA, K. 1997. Effects of leaf color, epicuticular wax amount and gramine content in barley hybrids on cereal aphid populations. Appl. Entomol. Zool. 32:1-8.

Ni, X. Z., and QuiSEnBERRY, S. S. 2003. Possible roles of esterase, glutathione S-transferase, and superoxide dismutase activities in understanding aphid-cereal interactions. Entomol. Exp. Appl. 108:187-195.

Rustamani, M. A., Kanehisa, K., Tsumuki, H., and Shiraga, T. 1992. Additional observations on aphid densities and gramine contents in barley lines. Appl. Entomol. Zool. 27:151-153.

SaKuma, M. 1998. Probit analysis of preference data. Appl. Entomol. Zool. 33:339-347.

SCHOtZKo, D. J., and BosQue-PÉREZ, N. A. 2000. Seasonal dynamics of cereal aphids on russian wheat aphid (Homoptera: Aphididae) susceptible and resistant wheats. J. Econ. Entomol. 93:975-981.

URBANSKA, A. 2007. Location and variablility of catalase activity within aphids. Electr. J. Polish Agric. Univ. 10(4). http://www. ejpau.media.pl/volume10/issue4/art-38.html

URBANSKA, A., and LESZCZYNSKI, B. 1992. Biochemical adaptations of cereal aphids to host-plants, pp. 277-279, in S. B. J. Menken, H. J. Visser \& P. Harrewijn (eds.). Proceedings of 8th International Symposium on Insect-Plant Relationships. Kluwer Academic Publishers, Dordrecht.

Vos, R. M. E., and van Bladeren, P. J. 1990. Glutathione Stransferases in relation to their role in the biotransformation of xenobiotics. Chem.-Biol. Interact. 75:241-265.

WANG, Y., CAI, Q. N., ZHANG, Q. W., and HAN, Y. 2006. Effect of the secondary substances from wheat on the growth and digestive physiology of cotton bollworm. Eur. J. Entomol. 103:255-258.

ZÚÑIGA, G. E., and CORCUERA, L. J. 1986. Effect of gramine in the resistance of barley seedlings to the aphid Rhopalosiphum padi. Entomol. Exp. Appl. 40:259-262. 